\title{
Industrial Policy, FDI and Employment: Still ‘Missing a Strategy’
}

\author{
David Bailey (Birmingham Business School) \\ Nigel Driffield (Aston University) ${ }^{1}$
}

\begin{abstract}
This paper contrasts the effects of trade, inward FDI and technological development upon the demand for skilled and unskilled workers in the UK. By focussing on industry level data panel data on smaller firms, the paper also contrasts these effects with those generated by large scale domestic investment. The analysis is placed within the broader context of shifts in British industrial policy, which has seen significant shifts from sectoral to horizontal measures and towards stressing the importance of SMEs, clusters and new technology, all delivered at the regional scale. This, however, is contrasted with continued elements of British and EU regional policy which have emphasised the attraction of inward investment in order to alleviate regional unemployment. The results suggest that such policies are not naturally compatible; that while both trade and FDI benefit skilled workers, they have adverse effects on the demand for unskilled labour in the UK. At the very least this suggests the need for a range of policies to tackle various targets (including in this case unemployment and social inclusion) and the need to integrate these into a coherent industrial strategy at various levels of governance, whether regional and/or national. This has important implications for the form of any 'new' industrial policy.
\end{abstract}

\section{Introduction}

Whilst 'industrial policy' in some form seems back on the agenda of politicians at the national and European levels, one dimension of industrial policy never really went away, namely the attraction of FDI in order to stimulate economic development. Indeed, for the much of the last quarter century, this could be seen as the dominant aspect of British industrial policy (Bailey et al, 1994, Driffield and Taylor, 2000) - and remains highly significant today. The consensus view amongst policy makers and international organisations is that FDI brings a 'package' of benefits including new technologies, skills upgrading, and the generation of jobs and exports (see for example EBRD, 1998). In the British case this has involved over many years the use of substantial subsidies to attract FDI.

The purpose of this paper is firstly to chart the evolution of British industrial policy in recent years, noting its key features in terms of discontinuity, inconsistency,

\footnotetext{
${ }^{1}$ The authors wish to acknowledge the support of the ESRC under award number RES-00022-0468.
} 
reactiveness and a general (with some exceptions) liberal stance. During the 1990s British industrial policy followed trends elsewhere in stressing the significance of 'competitiveness' (largely meaning productivity, albeit often obscured in the policy literature). Whilst potentially opening up a wide range of potential policy interventions, the apparent shift from sectoral to horizontal measures during the 1990s in fact largely reduced the content of national level industrial policy (Wren, 2001). Rather, there was a narrowing of focus around the coalescing themes of support for small firms, attraction of foreign firms (FDI) and science and technology, all increasingly delivered via a regionally-based approach. Indeed, during the late 1990s and post 2000 , British industrial policy has been recast at the regional level, with the new Regional Development Agencies (RDAs) given responsibility for delivering industrial policy, in terms of targeting so-called 'clusters', attracting FDI and a broader social inclusion agenda. FDI, traditionally seen as a cornerstone of regional policy, is still viewed as particularly important in this regionally-based industrial policy, with a continued focus on attracting FDI: (i) to reduce structural unemployment; and (ii) to reduce inequalities, both intra-regionally via reduced unemployment and interregionally via raised productivity through technology transfer and spillover effects.

The paper then moves on to examine the compatibility and effectiveness of two of these fundamental aims of regionally-delivered British industrial policy; the desire to increase skill intensities with British industry, and attracting inward investment in order to stimulate labour demand, particularly in those regions or industries that have experienced economic decline and restructuring over the past twenty years. By constructing and testing a model of labour demand for British manufacturing industry, we show that these two aspirations are to a large extent inconsistent. This in turn suggests the need for a broader approach to industrial policy, where more instruments are used to target these quite different policy goals within an overall strategy. This is a significant issue given that governments are now reappraising the role for and extent of a 'new industrial policy'. Furthermore, inward investment agencies such as Invest UK have been reappraising their own approach, targeting smaller investments in recent years, raising the question of how this fits in with the broader objectives highlighted above. Overall, there is a need to understand how a policy to attract and retain FDI fits with other aspects of a 'new industrial policy'; where it is consistent with other policy goals, where inconsistent, and what else needs to be done as part of any 'new' policy given the strategic objectives set by policy makers. We echo Cowling and Sugden (1993) in arguing that a strategic overview is required at regional and national levels in understanding how different 
policies should fit together.

This paper extends the work of Bailey and Driffield (2002), Driffield and Taylor (2000) and Taylor and Driffield (2005) in evaluating the impacts of FDI on employment in domestic firms. This literature, following Barrell and Pain (1997), demonstrates that inward investment generally acts to increase the relative demand for skilled labour, and in turn increases wage differentials between skilled and unskilled workers. However, this paper extends existing work in two novel ways. Firstly, we evaluate the effects of investment by large domestic firms as well as foreign firms, on the relative demand for skilled and unskilled labour, and secondly we allow for both trade and technology effects in factor demand.

\section{The Evolution of British Industrial Policy}

Whilst there is much disagreement on how best to characterise British industrial policy since the Second World War (Reynolds and Coates, 1996), cutting through the detail of that debate, key aspects of British industrial policy have arguably been discontinuity, inconsistency, reactiveness and a liberal stance, with a recent emphasis on 'competitiveness' (as noted above an often obscured term largely meaning productivity) and a decentralised approach focused on clusters.

Discontinuity has come with sharp reversals of certain policies as the ideologies of governments have differed, for example nationalisation in the 1960s and 1970s followed by privatisation from the 1980s until today. Similarly, a concern to promote large firms or "national champions" in the 1960s and 1970s gave way to a desire to support smaller firms later on, while an apparent focus on manufacturing in the 1960s and 1970s gave way to a 'neutral' stance on the issue of manufacturing versus services-led growth (Pitelis, 1994). The major exception has been the continuity seen in policy towards FDI and transnational corporations (TNCs), with both foreign- and British-based transnationals being given a free rein over many years (Bailey et al, 1994; 1999).

Inconsistency has also been seen in many areas of policy. In competition policy, for example, governments have accepted the need to correct for market failures, whilst at the same time maintaining weak and ineffective monopoly and merger policies (Pitelis, 1994). Although the post-1997 Labour governments have sought to strengthen some aspects of competition policy, Labour backtracked on proposals to tighten merger controls in the wake of business lobbying. More seriously, some commentators have argued that British experience has been one of "industrial policies without an industrial 
strategy" (Cowling and Sugden, 1993). ${ }^{2}$ In line with Pitelis (2003), industrial policies can be seen as measures designed to improve the performance of industry, whilst an industrial 'strategy' might consist of a well thought-out set of industrial policies that are reasonably consistent and coherent with the aim of realising well-defined, long-term objectives.

Taking this further, reactiveness is seen in the sense that policy has been characterised by re-active, ad-hoc measures taken in response to crises, whether the crisis in the coal industry or the BSE ('mad cow') scare in the 1990s, or more recently the Rover crisis in 2000 and the MG Rover collapse in $2005 .{ }^{3}$ Reactiveness is also seen in the motivation of government intervention itself. A reactive policy can be defined as one that solely reacts to correct market failures (externalities, public goods, monopolies etc.) or in response to crises. In contrast, as Jacquemin (1987, in Oughton, 1997) notes, a more proactive approach goes beyond market failure, and considers strategies which "deliberately influence the transformation and the industrial reorganization of sectors, and nations", noting that "in many sectors comparative advantages are based on partially controllable elements". He points to policies that might alter the accumulation of physical and human capital over time, which in turn might alter relative capital endowments. The experiences of MITI (whether or not one accepts how successful these were; see Bailey, 2003) up until the 1980s could be seen as such a pro-active approach, in contrast with British experience.

Connected with this reactive approach, it can be argued that British industrial policy over many years has on the whole been liberal, built on a belief that industrial performance is best left in private hands, assisted only at the margin by state activity (Reynolds and Coates, 1996). ${ }^{4}$ As Wilks (in Reynolds and Coates, 1996) notes,

"a major operational value of British industrial policy is not maintenance of market principles (as in Germany)... or the productivity of the enterprise (as in Japan) but rather a concern to sustain the autonomy of the firm. This concern might be regarded as the purest of market principles or, more correctly, as the ultimate market ethic, since it really presupposes that national economic

\footnotetext{
${ }^{2}$ Cowling and Sugden's definition of 'strategy' here goes beyond the coherence of industrial policies and includes a concern with strategic decision making $(1993,1994)$.

${ }^{3}$ The British government was heavily criticised for not foreseeing the Rover crisis in 2000, with the DTI in particular criticised for its lack of information gathering (House of Commons, 2000).

${ }^{4}$ This is rejected by Lee (1999) who argues that Britain has 'consistently implemented its own developmental strategy which has enthusiastically embraced technocratic departments of state, industrial policy and the sustained deployment of expertise in science and technology'. The difference with Germany and Japan, he argues, is that in Britain's' case this has been in the military rather than civilian sectors.
} 
benefit (good of all) is derived only from the individual's (in this case the individual firm's) interpretation and unfettered pursuit of personal benefit".

This is not to say that there have not been specific interventions at certain points in time, most notably in the 1960 s to encourage large size and to 'pick winners' or back so-called 'national champions' (Pitelis, 1994). However, there is widespread acceptance that such policies failed (Pitelis, 1994; Cowling et al, 1999). As a result, such sectoral measures were arguably withdrawn in the 1980s. The latter is viewed as a period of withdrawal of state support and a decline in regional expenditure and privatisation, with an apparent re-focusing of industrial policy around horizontal measures with the aim of "providing the right underlying conditions to catalyse and facilitate growth in the context of declining trade barriers and increased competition" (Oughton, 1997). However, as Oughton stresses, such a withdrawal was not complete; with $60 \%$ of the government R\&D budget remaining spent in just two sectors - defence and civil aerospace, 'the extent of the reorientation of industrial policy is open to question'. Somewhat controversially, El-Agraa (1997) suggests that industrial policy only comprises sectoral measures and that horizontal policy falls outside the remit of industrial policy. This view is out of line with traditional definitions of industrial policy and indeed with the literature suggesting a shift form sectoral to horizontal industrial policy in recent years (Cowling et al, 1999). Moreover, Cowling et al (1999) make the critical point that the perception of a shift towards horizontal measures is to a large extent misplaced as targeting of some form or another is an intrinsic part of virtually all industrial policies.

\subsection{The Rise of 'Competitiveness Policy'}

Leaving aside this question of the extent of the perceived shift from sectoral to horizontal support, it was certainly the case that the 1990s saw a re-assessment of industrial policy. Indeed, despite a generally laissez faire approach by the then Conservative governments, the 1994, 1995 and 1996 White Papers identified ten broad areas influencing so-called 'competitiveness', including: the macro economy, education and training, labour markets, innovation, management, fair and open markets, finance for business, communications and infrastructure, the commercial framework and government/business procurement (Oughton, 1997). As Wren rightly notes, these papers along with the 1998 Labour White Paper potentially broadened the scope of British industrial policy. Indeed, the 1994 White Paper alone identified over 300 measures to improve economic performance. In practice, however, the shift from 
sectoral to horizontal approaches 'in fact helped much reduce the content of this policy' (Wren, 2001).

With the concern for productivity growth, 'competitiveness' has become the 'Holy Grail' of industrial policy under the both Conservative and recent Labour governments (see DTI 1994, 1995, 1996 and 1998). In the British case, 'competitiveness' has had a potentially inconsistent, multi-level dimension. At the firm level, the British government (DTI, 1994) defined this largely in terms of productivity, as "the ability to produce the right goods and services of the right quality, at the right price, at the right time. It means meeting customers' needs more efficiently than other firms". At the national level, though, the much-quoted OECD (1992) definition was used. This is the degree to which the country can "under free and fair market conditions, produce goods and services which meet the test of international markets, while simultaneously maintaining and expanding the real incomes of its people in the long run". This is seen as both vague and unnecessarily restrictive by Pitelis (2003). While Porter (1990) suggested the substitution of the notion of national competitiveness with that of firms and sectors, Pitelis (2003) suggests that this is problematic in that the competitiveness of firms need not translate into an improvement of economic welfare of the country itself. In this vein, Oughton (1997) notes that firm-level and national definitions are only compatible if improved competitiveness at the firm level is achieved whilst maintaining employment levels nationally. A firm may down-size and shed labour to improve productivity and hence competitiveness but if the workers laid off are not absorbed by other firms or industries then part of the benefits accruing at the firm or industry level may be offset at the national level by the income reductions from the lay-offs.

For these reasons, Pitelis (2003) instead favours a broader definition of competitiveness defined as "the improvement of a subjectively defined welfare indicator for a country, over time and/or in relation to other countries". Whilst avoiding some of the problems of other definitions, Pitelis admits that the issue of how to choose a generally accepted welfare criterion remains. Branston et al (2006 forthcoming) see value in this definition, for example in capturing the term's relative nature of competitiveness, not in terms of localities in competition but rather their relative success as compared to others in achieving particular objectives. However, they see the subjective index as too vague and instead suggest a more focused perspective that sees competitiveness in terms of democratically determined objectives for development in a specific locality. To be competitive, they argue, is to 
satisfy those objectives effectively as compared to other localities. Whilst this could include success in international markets as in the DTI definition, it could potentially go much further. As they note, it also has the advantage of explaining the basis for choice; democracy. This is of particular relevance below, both in terms of the debate over cluster policy at the regional level, where policy can be seen as a revival of sectoral measures, and in terms of recognising the multi-faceted nature of competitiveness when it is broadly defined, thus requiring a variety of policy interventions.

Critically, the Conservative governments of the 1990s did not identify any British under-performance in investment (in fixed or intangible assets), and thus felt that no government intervention was required to improve the rate of investment. In contrast, during the 1990s the EU did prioritise the promotion of full employment, and hence the need to raise investment rates in Europe so as to increase capacity and productivity (Oughton, 1997). This lack of attention to employment as an issue in British industrial policy largely reflected the reduction in unemployment through the 1990s, in contrast with much of the rest of the EU (Wren, 2001). Labour's 1998 White Paper (DTI, 1998) represented a significant change in this respect in that it recognised, for the first time, the need to improve the rate of investment. The Labour government subsequently introduced a number of measures such as reform of the tax system on dividend payments in an attempt to encourage the retention of profits, the use of tax credits to raise investment in $R \& D$, and the introduction of Regional Venture Capital Funds to improve the supply of funding for small firms. In this sense some of the more interesting recent industrial policy measures have been run by the Treasury rather than the Department of Trade and Industry (DTI), reflecting the longterm dominance of the former in British economic policy making (Theakston, 1996).

Whilst the Labour Chancellor Gordon Brown has therefore introduced some interesting supply-side measures and competition policy has been strengthened in limited respects, the emphasis of industrial policy under Labour continues to be on competitiveness or productivity, albeit encompassing a new recognition of the need to improve the rate of investment (see also DTI, 2005), with a narrowing of focus around the merging themes of support for small firms, attraction of foreign firms, science and technology and regional development policy. Wren (2001) suggests that the 2001-2005 Labour government defined productivity growth as the key theme of economic policy, leading him to follow Krugman in stating that "for competitiveness we can read productivity". Similarly, Branston et al (2006 forthcoming) note that the 
1998 White paper placed a heavy emphasis on competitiveness in terms of productivity, innovation and high-value, which they saw as "partial and blinkered approach, defined in terms of market success; all that altered was the criteria emphasised in the free market game".

It is interesting to note here that industrial policy has almost become wholly divorced from trade policy. Indeed, despite the theoretical analysis of strategic trade policy, such as the work by Brander and Spencer (1985) or Eaton and Grossman (1986), intervention in trade is no longer on the political agenda. Indeed, most current policy analysis is based firmly on the view that free trade is wholly beneficial, to both exporting and importing countries.

More recently still, in line with the European Commission, the DTI has stressed that "competitiveness increasingly relies on a country's appropriate structures of roles, institutions and processes to enable, organise, and drive efforts to improve business environment and clusters" (Porter and Ketels, 2003). It is to this which we turn next.

\subsection{Regions and Clusters: A New Paradigm or Sectors All over Again?}

Most notable since 1997 has been the decentralisation of industrial policy to Regional Development Agencies in the English regions, modelled on experience in Scotland, albeit with significantly less funding. These have provided the opportunity at least for more pro-active policies to be developed at the regional level, generally via two main and interlinked economic development strategies: the attraction of transnationals and the support of clusters via cluster policies. Indeed, a key feature of the 1998 White Paper under Labour was the signalling of exactly this shift towards a focus on higher quality inward investment and to emphasising clusters.

Underpinning this shift to the regional level as the focus for industrial policy design and delivery in Britain and elsewhere has been an apparent intellectual legitimacy granted by the so-called 'New Regionalism' (NR) perspective that has gained currency amongst scholars and the policy community in recent years. The NR is shorthand for various streams of literature that have emphasised the significance of the regional level as the most effective basis for post-Fordist economic management. Its origins lay with studies of the post-Fordist mode of flexible specialisation by researchers such as Piore and Sabel (1984), Markusen (1996) and Storper (1995, 1997) which looked at the success stories of the new "industrial spaces" such as Silicon Valley and Rhone Alps, and which drew on Beccatini's seminal work on Italian 
industrial districts (Pyke et al, 1990). Following the identification of these regionally based, flexible specialisation success stories, researchers from various disciplines have emphasised the regional level of analysis (see Bailey, 2003a). ${ }^{5}$ Whilst emerging from varying discourses, these approaches share a common view that regional success or competitive advantage is to a large part embedded in social capital (Putnam, 1993). The end result was the predominant view that far from heralding the end of geography, globalisation is instead prompting a refocusing on localized geographical agglomeration and spatial clustering, with "the regional scale canonized as a 'functional space' for economic planning and political governance" (see MacLeod, 2001). And it was Porter himself who argued that "competitive advantage is created and sustained through a highly localized process" where "national competitive advantage... resides as much at the level of the cluster as it does in individual industries" (Porter, 1998).

Against the backdrop of this broader intellectual debate focusing on the regional scale and clusters, and the evolution and acceptance of these concepts in the policy community, British industrial policy post-1997 was effectively re-orientated around the regional scale through RDAs with an emphasis on cluster policies a la Porter. It has become de rigueur to accept that the regional scale to industrial policy is vital in delivering competitiveness, and in turn needs to build and support regionally-based clusters underpinned by social capital, organisational capacity and the provision of collective services. However, the assumptions underpinning this industrial policy paradigm shift have not gone without criticisms. For example, clusters have been criticised as "old wine in new bottles" (McCrone, 1999) and too vague a concept to be useful. Some see the term as a simple 're-badging' in many cases of sectors (Peck and McGuiness, 2003, in Waters and Smith, 2002) while Martin and Sunley (2003) see it as a 'chaotic concept' which should carry a 'public policy health warning'. The latter note that building successful clusters can bring advantages in terms of increased innovation, growth, productivity, competitiveness, new firm formation and higher job growth. However, they note potential costs in terms of the danger of technological isomorphism, labour cost inflation, inflation of land and housing costs,

\footnotetext{
${ }^{5}$ See Piore and Sable (1984) on 'regional conglomerations' of firms; Saxenian (1994) on the relative regional advantage of Route 128 and Silicon Valley; Amin and Thrift (1994) on the 'institutional thickness' of regions; Florida (1995) on US 'learning regions'; Storper (1995) on the region as a 'nexus of untraded interdependencies'; Scott (1996) on regions as 'motors' in the new economic order; and Cooke and Morgan (1998) on the 'associational economy' of some European regions.
} 
widening income disparities, institutional and industrial lock-in, over-specialisation and local congestion and environmental pressure (ibid).

In practical policy-application terms, there is also considerable confusion over what the term 'cluster' actually means (see for example Bailey, 2003a). Tully and Berkeley (2004) even suggest that many RDAs now prefer the term 'sector' and are "quietly walking away from the cluster concept, but are just not telling the DTI". Although too early to confirm, whilst nationally there has been a shift from sectoral to horizontal approaches, more locally we may now be observing the re-emergence of sectoral policies all over again, where the ubiquitous regionally-based cluster policy can be seen as a new form of localised industrial targeting, with similar inherent dangers as at the national level of picking the 'wrong' 'clusters' if the selection process is dominated by an elite group and selection processes are not democratic (Cowling et al, 1999). ${ }^{6}$ This links back to earlier definitions of competitiveness; a democratic process of cluster selection could be seen as crucial if a society is to target the development of competitive clusters.

This in turns links with Lovering's comments on the dangers inherent within such approaches of diverting public resources to supporting a special set of interests (Lovering, 2001) and the need to deflate the new regionalism "hegemony" in part through a more "genuinely pluralistic approach to strategy formation" (Lovering, 1999). Echoing Markusen (1996) we can say that regionally-based clusters and hence polices are slippery concepts in slippery spaces.

In practical terms, it needs to be recognised that 'clusters' and/or sectors often extend well beyond the region in question and that an isolated regional initiative may not be enough: linked initiatives across regions, perhaps co-ordinated nationally, are required to assist some clusters. Whilst the regionalisation of industrial policy in Britain through decentralisation to RDAs has brought genuine advantages in developing and tailoring industrial policies to suit local needs, it also brings possible dangers in the form of competing and overlapping regional initiatives that are insufficiently co-ordinated when the 'cluster' or sector in question extends across regional borders. As Peck and McGuiness (2001, in Waters and Lawton Smith, 2002) note "the alternative involving greater collaboration between regions in

\footnotetext{
${ }^{6}$ Although it should be noted that there are powerful arguments for conducting industrial policy at as local a scale a possible (see Begg et al, 1995).
} 
developing cluster strategies has yet to be taken seriously". Despite, or perhaps because of, the retrenchment of national-level industrial policy in Britain and the shift to the regional scale, there is clearly a key role for national level coordination of regional strategies. At the moment this is lacking.

Paradoxically, simultaneous to this lack of inter-RDA coordination of cluster policies, central government in Britain has been excessively restrictive and interventionist over exactly which clusters and technologies to support as part of regionally delivered industrial policies. Indeed, Charles and Benneworth (2001) argue that it has determined which clusters are important and has refused to delegate science and technology policy to the regional level. ${ }^{7}$ This might help to explain why the clusters targeted by different RDAs across the UK are so remarkably similar. Indeed, many target the same 'list' (including automotive, ICT, creative industries and media, food and drink, and biotechnology). Andriani et al (2005) note the "astonishing overlap" in regional cluster policies, commenting that "it stretches credibility to believe that the UK could be home to half a dozen or more successful biotech clusters. Thus most strategies (if not all) will fail, raising the question of whether this constitutes an appropriate direction of public funds".

At another scale but in similar vein, Waters and Lawton Smith (2002) argue against "the local application of top-down policy". This top-down, dirigiste approach has been heightened by central government constraints on the limited resources available to the English RDAs in comparison with devolved agencies in Scotland and Wales (see Lee, 1999; Bailey, 2003a). Whilst the total budget of RDAs rose by $£ 500$ million to $£ 1.2$ billion in 2003, individual budgets remain dwarfed by their Scottish equivalent. In the West Midlands case the retention of the $£ 129$ million of RSA assistance within the region (which was initially earmarked for a BMW investment) in 2000 and another $£ 150$ million of government assistance in 2005 can be seen as an implicit recognition that the RDA did not have sufficient resources to tackle a problem of the scale of the MG Rover collapse. Furthermore, RDAs in general have faced limited flexibility over the limited spending available to them, being heavily constrained by pre-ordained first by top-down 'silos' of funding and then by very specific central government target setting (Fuller et al, 2002). The paradox thus arises that RDAs are overly constrained in terms of their ability to pursue strategic objectives in terms of regional industrial

7 Despite the apparent shift away sectoral industrial policy in the 1990s noted above, paradoxically science and technology policy became highly interventionist through the use of 'sector panels' and greater control by government and industry over the agenda for basic research, echoing the 'old approach to industrial policy of 'picking winners" (Oughton, 1997). 
policy, but that their efforts to foster the development of local 'clusters' or 'sectors' are insufficiently coordinated on a national or inter-regional basis (Bailey, 2003a).

National level policy over a range of issues is not neutral in this respect, with the broader role of central government crucial in constraining or facilitating regional level policy initiatives. Indeed, even the most sophisticated regional-level industrial policy can run into the constraints and incompatibilities of national-level policy. For example, 'cluster' policies and more general industrial policy goals in a manufacturing-orientated region can be undermined by major exchange rate fluctuations (Bailey, 2003a). Furthermore, whilst it is widely accepted that local production systems can be improved by firms - whether domestic or foreign - that bring new technology and investment, they can also be damaged through takeovers. Indeed, Harrison (1994) notes that incoming firms often bring engineering talent to clusters, a commitment to manufacturing excellence, and access to overseas markets, but not a commitment to local economic development. National level competition policy needs to take this on board in protecting local production systems for example via monitoring the impact of incoming firms (see Bailey et al, 1999). What might be relevant here is monitoring at a sub-national level as part of regional industrial policy so as to inform and develop national-level policy on takeovers. In this way national and regional level policy could be coordinated, and a regional dimension added to competition policy (Bailey, 2003a).

This can be extended to encompass policies aimed at attracting FDI. The possibility that FDI can act as a channel to promote new 'cluster' formation has become increasingly explicit. However, FDI-generated clusters have often proven to be fragile, short-term, and driven in a top-down manner. All too often, the transnational does not embed itself in the locality but simply relocates if economic conditions change. There tends to be little or no technology transfer and, if there are spin-offs from the transnational these tend to be to sub-contractors for whom the transnational is the only buyer. De Propris and Driffield (2005) present an analysis of this, suggesting that while pre-existing clusters are attractive to inward investors, there is less evidence that inward FDI acts as a conduit to cluster formation. This raises the need for the careful use of policy to attract FDI that complements embedded cluster development, rather than attempting to build clusters in a 'top-down' way around mobile transnationals. It is to FDI policy that we turn next. 


\section{$2.4 \quad$ FDI Policy}

As noted in the introduction, the British government has welcomed incoming FDI for bringing "new jobs, new management techniques, innovation, dynamism and competition to the economy" (Blair, 2002), and has backed this up with substantial subsidies. $^{8}$ This view is supported by academics such as Eltis (1996) who see foreign transnationals in particular as raising quality and productivity levels. ${ }^{9}$ At the regional level the emphasis for many years for the less favoured regions of Britain has been on alleviating structural unemployment via inward investment inflows (Yannopoulos and Dunning, 1976) using regional support for assisted areas (Gripaios et al, 1997). With the decentralisation of industrial policy to RDAs noted above, there has been intensified competition between agencies to attract FDI through subsidy packages. ${ }^{10}$ The RDAs generally pursue two main and interlinked economic development strategies in creating and supporting employment: the attraction of transnationals and the support of clusters via cluster policies, with the latter often dependent on the former through monopsonistic supply chains based around foreign investors such as in the car or electronics industry. Such approaches form part of wider regional economic strategies that stress the need to foster social inclusion and reduced long-term unemployment (see for example Advantage West Midlands, 1999 and Benneworth, 2001). ${ }^{11}$

In fact during the 1990s there was something of a re-emphasising of the role of inward investment for regional development after a decade or so of emphasis in industrial policy on the potential of small firms and indigenous entrepreneurship. ${ }^{12}$ Partly, as Amin and Tomaney (1995) note, this can be related to the sense amongst

\footnotetext{
${ }^{8}$ Evidence on this support is limited. Brech and Sharp (1984) estimated that in 1981-1982 the overall level of assistance offered by the British government to incoming transnationals was $£ 1.5$ billion. Excluding tax relief their estimate was $£ 370$ million. Girma et al (2001) note that in attracting Samsung and Siemens to the North East, the British government provided \$30 000 and $\$ 50000$ per worker respectively, while Cowling et al (1999) cite a figure of $£ 42,000$ subsidy per job created in attracting FDI to Wales in the late 1990s.

${ }^{9}$ See Girma et al (2001). Driffield (2001) explores the subtleties involved in evaluating the effects of FDI in bringing superior technology, such as the motivation behind the investment.

${ }^{10}$ Witness for example the bidding war in 1997 between two British regions, Wales and the North, to win a plant of the Taiwanese-based computer firm Acer.

${ }^{11}$ See the Regional Economic Strategy of Advantage West Midlands which stresses the need for "greater social and economic cohesiveness" and the need to make opportunities "accessible to those people who are experiencing social exclusion" (Advantage West Midlands, 1999: 3). It also notes the need to tackle "concentrations of high unemployment and accompanying social deprivation" (ibid).

${ }^{12}$ Which in turn came after the wave of branch plants established in the 1960s and 1970s failed to deliver an industrialisation benefiting regional host economies through skills upgrading, technology transfer, linkages, new management techniques or retained profits (see Amin and Tomaney, 1995).
} 
some researchers that the nature of the multi-locational firm was changing with a distinction drawn between the traditional top-down 'cost-driven' transnational and the so-called 'performance firm' which "derives its competitive advantage from product excellence and seeks locations which can offer qualified personnel and innovationrich environments" (see Amin and Tomaney, 1995). The latter is seen as bringing a range of attributes - including a wider range of functions, local decision-making authority, more extensive and superior local linkages and a more strategic position within the firm - which are more likely to benefit regional host economies. Yet in reality, as Amin and Tomaney (1995) note, in less favoured regions the term "flagship" often more appropriately refers to the international reputation of the firm, not the quality of the inward investment. Such 'performance' plants are few and far between in peripheral regions and seem instead to locate in core regions.

For the British regions at least the emphasis has been on using inward investment to: (i) reduce structural unemployment; and (ii) to reduce inequalities, both intraregionally via (i) and inter-regionally via raised productivity through technology transfer and spillover effects.

\section{FDI and domestic employment}

Having reviewed the development of British industrial policy above, our purpose now is to examine the compatibility and effectiveness of two fundamental aims of regionally-delivered British industrial policy, i.e. the desire to increase skill intensities and attracting inward investment in order to stimulate labour demand, particularly in such regions and/or industries that have experienced economic decline and restructuring. The model used is based on a relatively standard factor demand, following Barrell and Pain (1997, 1999) for example. Barrell and Pain (1997, 1999) focus on the demand for unskilled labour as an indicator of technological change, and while our model is employed in a similar spirit, it seeks to capture wider effects than merely new technology replacing unskilled workers, including an analysis on the effects on the demand for skilled workers.

We extend the analysis of Barrell and Pain (1997) in several ways. Firstly, in line with the large and developing FDI spillovers literature, we distinguish between foreign and domestic owned sectors of the UK. ${ }^{13}$ Furthermore, we also focus on smaller

\footnotetext{
${ }^{13}$ For a discussion of the FDI spillovers literature within the context of UK regional policy see Driffield (2005), or for a wider discussion see Görg and Strobl (2001) or Görg and Greenaway (2004).
} 
manufacturing firms, by examining the effects on firms other than the leading five in a given industry. Most policy initiatives, as discussed above, are targeted at these firms, and yet much current analysis ignores this when evaluating the effects of FDI, by employing data which by construction focuses attention on the largest firms. Constructing a broader data set in this way offers a further extension, in that we are able to contrast the effects of inward investment on labour demand, with the effects generated by investment by large UK owned firms. The extent to which there is a difference between these effects will offer a greater understanding of the importance and effectiveness of FDI policy within the context of UK industrial policy.

\subsection{The Model}

A full discussion of this is provided in Barrell and Pain (1997): however, to summarise, starting with a standard CES production function:

$$
Q=\gamma\left[s(K)^{-\rho}+(1-s)\left(L e^{\lambda t}\right)^{-\rho}\right]^{-1 / \rho}
$$

where $\mathrm{A}>0$, and $0<\mathrm{S}<1$. Returns to scale are given by: $[s \div(1+s)] \times(K \div L)^{\rho+1}$.

The elasticity of substitution is given by $(\rho / 1+\rho)$ and $t$ represents exogenous technological change. Thus, it is possible to derive a demand for labour equation:

$$
\ln (L)=\ln (Q)-\frac{1}{1+\rho} \ln (w / p)-\frac{\rho}{1+\rho} \lambda t+\left[\frac{1}{1+\rho} \ln \{1-s / \beta\}-\frac{\rho}{1+\rho} \ln (\gamma)\right]
$$

$$
=\ln (Q)-\sigma \ln (w / p)-(1-\sigma) \lambda t+[\sigma \ln \{1-s / \beta\}-(1-\sigma) \ln (\gamma)]
$$

The $\lambda t$ term then captures exogenous changes in factor demand, that Barrell and Pain $(1997,1999)$ relate to FDI and a time trend. We extend this firstly to distinguish between the long run effects of FDI (foreign share of an industry) and new FDI effects. Barrell and Pain (1997) ascribe all the effect of inward FDI acting to reduce the demand for unskilled labour to a "long run" technology effect, as inward investment introduces new technology then the demand for skilled labour is reduced. However, if one considers the effect of new inward FDI on incumbent firms, then there is also the possibility of a competitive or crowding out process, as inward investment crowds out domestic firms. Thus, we also include new flows of inward investment in our analysis. Further, to capture additional effects though R\&D expenditure, exports, and capital investment by large UK firms (DI5). The definitions 
and some descriptive statistics of these variables are given below. Specifically this employs data for the largest five firms in a given industry.

As such the expression for $\lambda t$ becomes:

$$
\lambda t=\delta_{1} T I M E+\delta_{2} \ln I F D I+\delta_{3} \ln I M P+\delta_{4} \ln D I+\delta_{5} \ln R D
$$

As such, the final equation that is estimated becomes:

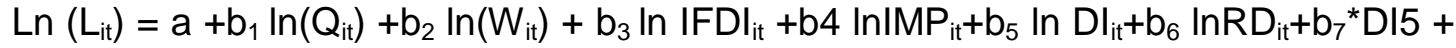
$b_{8} \ln \left(\right.$ FSHARE $\left._{i t}\right)+u_{i t}$

Where $u_{i t}=a_{i}+\mu t+\varepsilon_{i t}$

There is however a further consideration, that there is a degree of persistence in $L_{i t}$, such that lagged values of $L_{\text {it }}$ should be included in the model. (4) therefore becomes a dynamic equation:

$\operatorname{Ln}\left(L_{i t}\right)=a+b_{0} L_{i t-1}+b_{1} \ln \left(Q_{i t}\right)+b_{2} \ln \left(W_{i t}\right)+b_{3} \ln \left(I F D I_{i t}\right)+b 4 \ln \left(I M P_{i t}\right)+b_{5} \ln \left(D I_{i t}\right)+b_{6}$ $\ln \left(R D_{i t}\right)+b_{7}{ }^{*} \ln \left(D_{i t}\right)+b_{8} \ln \left(\right.$ FSHARE $\left._{i t}\right)+u_{i t}$

Furthermore, we offer an additional extension of this approach, by incorporating a partial adjustment process in factor demand, such that one is modelling changes in employment towards equilibrium, as well as explaining the static employment level. This is crucial when considering the external impacts on employment, as it allows for a distinction between internal moves towards equilibrium, and changes as a result of external pressures, following Hamermesh (1995). (5) then becomes:

$\Delta \ln \left(\mathrm{L}_{\mathrm{it}}\right)=\mathrm{a}+\mathrm{b}_{0} \Delta \mathrm{L}_{\mathrm{it}-1}+\mathrm{b}_{1} \Delta \ln \left(\mathrm{Q}_{\mathrm{it}}\right)+\mathrm{b}_{2} \Delta \mathrm{ln}\left(\mathrm{W}_{\mathrm{it}}\right)+\mathrm{b}_{3} \Delta \mathrm{ln} \mathrm{IFDI}_{\mathrm{it}}+\mathrm{b} 4 \Delta \ln \mathrm{IMP}_{\mathrm{it}}+$

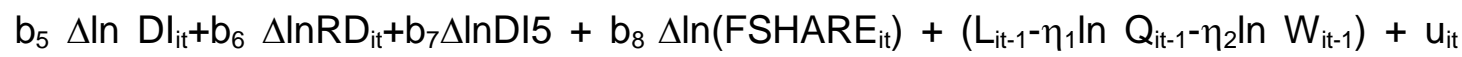
...(6)

\subsection{The Data}

The data used here are for the UK sector only, and for firms other than the leading five in any given industry. The UK Office of National Statistics (ONS) provided the foreign ownership data used here. These are derived from the raw data on which the Annual Business Inquiry ( $\mathrm{ABI}$ ), formerly the Census of Production (CP) is based. ${ }^{14}$ The definitions of value added, capital investment and the distinction between manual and non-manual workers can be found in any UK Annual Business Inquiry, or at www.statistics.gov.uk. The data used here are industry level data (3 digit) data for

\footnotetext{
${ }^{14}$ Further discussion of the data collection methodology is provided in Jones (2002).
} 
the period from 1980-1996 (after which any consistent skilled / unskilled distinction is removed from the UK census $)^{15}$. The data allow us to distinguish between investment by foreign firms, and investment by large UK owned firms, in terms of the effects that this investment has on the remainder of the sector. As such, the analysis focuses on the domestic sector, and also firms other than the largest five in any given 3 digit industry. All the data are annual, and all monetary data are deflated using the appropriate 3 digit industry consumer price index.

\section{The variables}

Dependent variable:

$\mathrm{L}$ : total employment of skilled or unskilled workers in the domestic sector excluding the top 5 leading firms.

Structural variables:

W: annual industry level average wages for skilled or unskilled workers workers in the domestic sector excluding the top 5 leading firms.

$\mathrm{Q}$ : value added at the industry level workers in the domestic sector excluding the top 5 leading firms.

Exogenous variables:

IFDI: industry level capital expenditure by foreign owned firms in the UK IMPORTS: industry level imports

DI: capital expenditure by the five largest domestic firms in the industry

$R D$ : Industry level $R \& D$, calculated using a perpetual inventory method and a depreciation rate of $10 \%$.

FSHARE: the share of employment of foreign owned firms at the industry level.

Table 1 illustrates some descriptive statistics for these variables. Foreign owned firms in the UK accounted for some $29 \%$ of value added over the period, and inward investment accounted for more than double the capital investment by the largest UK firms. It is also noticeable that the distribution of foreign penetration across industries is far from uniform, ranging from two three digit sectors that had no foreign involvement, through to sectors such as chemicals, office machinery, motor and other vehicles and the wood industry that are dominated by foreign ownership.

Table 1 here.

15 Data for these series are available from 1980-1996 inclusive. However, these was a change in the Standard Industry Classification in 1992, rendering the construction of a consistent panel impossible. However, it is possible to link the series across the break, such that while it remained impossible to estimate a consistent model for the full time series, further lags of the structural variables could be used as instruments in the estimation. Due to this, it is possible to employ the GMM-IV estimation to the full period 1993-1996. 


\subsection{Estimation}

The estimation problems of dynamic models from short panels are well documented in the econometric literature (see Baltagi, 2005 and references therein). The essential difficulty lies in the fact that, in the presence of fixed effects, the lagged dependent variable is correlated with the disturbance term. Standard 'within' transformation typically used in static models fails to deliver consistent estimators. A popular way of circumventing this problem is to remove the fixed effects via firstdifferencing, and instrumenting the lagged dependent variable with further lagged values. One can then employ a variant of the instrumental variable estimation technique (e.g. GMM-IV). However, the partial adjustment model (6) implies a dynamic model in first differences. Our approach of estimating the system of dynamic panel equations is in the spirit of Holtz-Eakin et al (1988), using lagged values as instruments to generate orthogonality conditions on differenced data, and employing GMM. This is a slight variation on the more standard GMM estimator suggested by Arellano and Bond $(1988,1991)$ due to the presence of the partial adjustment term, The estimator employed here is discussed in some detail in Hamermesh (1995), and generates heteroscedastic-consistent estimates. We also test for $1^{\text {st }}$ and $2^{\text {nd }}$ order serial correlation: (Doornik et al. 2002). The appropriate AR1 and AR2 tests are then based on average residual autovariances, which are asymptotically distributed $\mathrm{N}(0,1)$. Due to the problems of obtaining a consistent time series due to the structural break, the model is estimated for the two sub-samples, 1984-1992 and 1993-1996. 
(a) Results for 1993-1996.

i. Unskilled labour

\begin{tabular}{|c|c|c|c|c|}
\hline Parameter & Estimate & Error & t-statistic & P-value \\
\hline$\Delta \mathrm{Li}_{\mathrm{t}-1}$ & .245706 & .139307 & $1.76377^{\star}$ & {$[.078]$} \\
\hline \multicolumn{5}{|c|}{ Structural terms } \\
\hline$\Delta Q_{i t}$ & .075099 & .023118 & 3.24846 ** & {$[.001]$} \\
\hline$\Delta \mathrm{W}_{\mathrm{it}}$ & -.334426 & .094081 & $3.55465^{\star \star}$ & {$[.000]$} \\
\hline \multicolumn{5}{|c|}{ Exogenous terms } \\
\hline $\mathrm{FDI}_{i+1}$ & -.012854 & .00277 & $-4.63730^{* \star}$ & {$[.000]$} \\
\hline Fshare $_{\mathrm{it}-1}$ & -.039975 & .030407 & -1.31465 & {$[.189]$} \\
\hline $\mathrm{Dl}_{\mathrm{it}-1}$ & .011051 & .021305 & .518730 & {$[.604]$} \\
\hline$R_{\text {it- } 1}$ & .024280 & .045817 & .529929 & {$[.596]$} \\
\hline Import $_{\text {it-1 }}$ & .027647 & .018451 & $1.49846^{*}$ & {$[.134]$} \\
\hline \multicolumn{5}{|c|}{ Partial adjustment terms } \\
\hline$Q_{\text {it }}$ & .678613 & .057532 & $11.7954^{\star \star}$ & {$[.000]$} \\
\hline$W_{\text {it }}$ & -.418039 & .067010 & $-6.23846^{\star *}$ & {$[.000]$} \\
\hline \multicolumn{2}{|c|}{ Sargan $p$ value } & \multicolumn{3}{|c|}{0.109} \\
\hline \multicolumn{2}{|c|}{$\mathrm{AR}(1), p$ value } & \multicolumn{3}{|c|}{$-4.068(0.044)$} \\
\hline \multicolumn{2}{|c|}{$\mathrm{AR}(2), p$ value } & \multicolumn{3}{|c|}{$1.823(0.177)$} \\
\hline \multicolumn{2}{|c|}{ Goodness of fit: Corr $(y, \hat{y})$} & \multicolumn{3}{|c|}{0.719} \\
\hline
\end{tabular}

Standard Errors computed from heteroscedastic-consistent matrix

\section{ii. Skilled Labour}

\begin{tabular}{|c|c|c|c|c|}
\hline Parameter & Estimate & Error & t-statistic & P-value \\
\hline$\Delta \mathrm{Li}_{\mathrm{t}-1}$ & .072942 & .055683 & 1.30996 & {$[.190]$} \\
\hline \multicolumn{5}{|c|}{ Structural terms } \\
\hline$\Delta \mathrm{Q}_{\mathrm{it}}$ & .086329 & .015621 & $5.52635^{\star \star}$ & {$[.000]$} \\
\hline$\Delta \mathrm{W}_{\mathrm{it}}$ & -.375343 & .083440 & $-4.49834^{* *}$ & {$[.000]$} \\
\hline \multicolumn{5}{|c|}{ Exogenous terms } \\
\hline $\mathrm{FDl}_{\mathrm{it}-1}$ & -.002113 & .001482 & -1.42615 & {$[.154]$} \\
\hline Fshare $_{i t-1}$ & -.019918 & .012759 & $-1.56106^{*}$ & [.119] \\
\hline $\mathrm{DI}_{\text {it- } 1}$ & .003267 & .006684 & .488812 & {$[.625]$} \\
\hline$R D_{\text {it }-1}$ & -.031276 & .020982 & $-1.49059^{\star}$ & {$[.136]$} \\
\hline Import $_{\text {it-1 }}$ & .028806 & .011436 & $2.51901^{* *}$ & {$[.012]$} \\
\hline \multicolumn{5}{|c|}{ Partial adjustment terms } \\
\hline $\mathrm{Q}_{\mathrm{it}}$ & .475018 & .036165 & 13.1347 & {$[.000]$} \\
\hline $\mathrm{W}_{\mathrm{it}}$ & -.187757 & .0150947 & -12.438 & {$[.000]$} \\
\hline \multicolumn{3}{|c|}{ Sargan $p$ value } & \multicolumn{2}{|c|}{0.336} \\
\hline \multicolumn{3}{|c|}{$\mathrm{AR}(1), p$ value } & \multicolumn{2}{|c|}{$-3.598(0.058)$} \\
\hline \multicolumn{2}{|c|}{$\mathrm{AR}(2), p$ value } & & \multicolumn{2}{|c|}{$1.171(0.187)$} \\
\hline \multicolumn{2}{|c|}{ Goodness of fit: Corr $(y, \hat{y})$} & & \multicolumn{2}{|c|}{0.662} \\
\hline
\end{tabular}


(b) Results for $1984-1992$

i. Unskilled labour

\begin{tabular}{|c|c|c|c|c|}
\hline Parameter & Estimate & Error & t-statistic & P-value \\
\hline$\Delta \mathrm{Li}_{\mathrm{t}-1}$ & .26133 & .17905 & 1.4595 & {$[.074]$} \\
\hline \multicolumn{5}{|c|}{ Structural terms } \\
\hline$\Delta Q_{i t}$ & .08246 & .024114 & $3.41966^{* *}$ & {$[.000]$} \\
\hline$\Delta \mathrm{W}_{\text {it }}$ & -0.34799 & .10293 & $3.38092^{* \star}$ & {$[.001]$} \\
\hline \multicolumn{5}{|c|}{ Exogenous terms } \\
\hline & & & & \\
\hline FDI $_{\text {it-1 }}$ & -.12250 & .02970 & $-4.12392^{\star \star}$ & {$[.000]$} \\
\hline Fshare $_{i t-1}$ & -.03446 & .030357 & 1.13542 & [.129] \\
\hline DI5 $_{\text {it- } 1}$ & .009946 & .02068 & .48082 & [.316] \\
\hline$R D_{\text {it-1 }}$ & -.025609 & .042011 & .60956 & {$[.272]$} \\
\hline Import $_{\text {it-1 }}$ & .028850 & .022213 & 1.29877 & [.099] \\
\hline \multicolumn{5}{|c|}{ Partial adjustment terms } \\
\hline$Q_{\text {it }}$ & .59139 & .041989 & $14.0845^{\star *}$ & {$[.000]$} \\
\hline$W_{\text {it }}$ & -.46309 & .074900 & $-6.18268^{\star \star}$ & {$[.000]$} \\
\hline \multicolumn{2}{|c|}{ Sargan $p$ value } & \multicolumn{3}{|c|}{0.322} \\
\hline \multicolumn{2}{|c|}{$\mathrm{AR}(1), p$ value } & \multicolumn{3}{|c|}{$-4.243(0.039)$} \\
\hline \multicolumn{2}{|c|}{$\mathrm{AR}(2), p$ value } & \multicolumn{3}{|c|}{$1.578(0.209)$} \\
\hline \multicolumn{2}{|c|}{ Goodness of fit: Corr $(y, \hat{y})$} & \multicolumn{3}{|c|}{0.771} \\
\hline
\end{tabular}

Standard Errors computed from heteroscedastic-consistent matrix

\section{ii. Skilled Labour}

\begin{tabular}{|c|c|c|c|c|}
\hline Parameter & Estimate & Error & t-statistic & P-value \\
\hline$\Delta \mathrm{Li}_{\mathrm{t}-1}$ & .07102 & .04724 & $1.5035^{*}$ & {$[.068]$} \\
\hline \multicolumn{5}{|c|}{ Structural terms } \\
\hline$\Delta \mathrm{Q}_{\mathrm{it}}$ & .10137 & .021253 & $4.7696^{\star \star}$ & {$[.000]$} \\
\hline$\Delta \mathrm{W}_{\mathrm{it}}$ & -.39186 & .010552 & -3.7135 & {$[.000]$} \\
\hline \multicolumn{5}{|c|}{ Exogenous terms } \\
\hline $\mathrm{FDl}_{\mathrm{it}-1}$ & -.018677 & .011395 & $-1.6391^{*}$ & {$[.052]$} \\
\hline Fshare $_{i t-1}$ & -.017497 & .011373 & -1.5384 & {$[.064]$} \\
\hline $\mathrm{DI}_{\text {it- } 1}$ & .003263 & .005794 & .56326 & {$[.288]$} \\
\hline $\mathrm{RD}_{\text {it-1 }}$ & -.032183 & .022766 & -1.4137 & {$[.080]$} \\
\hline Import $_{\text {it-1 }}$ & .032926 & .013468 & $2.4447^{* \star}$ & {$[.008]$} \\
\hline \multicolumn{5}{|c|}{ Partial adjustment terms } \\
\hline $\mathrm{Q}_{\mathrm{it}}$ & .398316 & .032253 & $12.3496^{* *}$ & {$[.000]$} \\
\hline $\mathrm{W}_{\mathrm{it}}$ & -.17676 & .014732 & $-11.998^{\star *}$ & {$[.000]$} \\
\hline \multicolumn{3}{|c|}{ Sargan $p$ value } & \multicolumn{2}{|c|}{0.264} \\
\hline \multicolumn{3}{|c|}{$\mathrm{AR}(1), p$ value } & \multicolumn{2}{|c|}{$-4.057(0.044)$} \\
\hline \multicolumn{3}{|c|}{$\mathrm{AR}(2), p$ value } & \multicolumn{2}{|c|}{$2.569(0.109)$} \\
\hline \multicolumn{2}{|c|}{ Goodness of fit: Corr $(y, \hat{y})$} & & \multicolumn{2}{|c|}{0.659} \\
\hline
\end{tabular}


The first point to note is that the model behaves broadly similar across the two sub samples. This confirms the general modelling strategy, and also highlights few differences in the results over time. As anticipated, the elasticities of employment with respect to output and wages, in both the structural terms and partial adjustment terms, are large and significant. The results confirm that inward FDI does indeed impact on labour demand. Interestingly, this effect is significantly greater for the earlier time period, when UK manufacturing was declining rapidly. Specifically, inward investment acts to reduce employment of unskilled labour in UK firms, though the effect is relatively small for the period 1993-1996. What is clear from these results is that this decline in unskilled labour is not due to the "technology" effect of FDI, as this would be captured by the foreign share variable, as in Barrell and Pain (1997). Rather this is due to new foreign investment crowding out domestic employment. Indeed, the foreign share effect, while negative, is insignificant for both time periods. These results also illustrate the differential effect between the impacts of foreign and domestic large scale investment, with large scale domestic investment having no discernable effect on employment in UK firms.

Interestingly, imports appear to have a positive effect on employment, particularly of skilled workers, suggesting that imports by manufacturing industries are of components rather than finished goods. While this result may be considered surprising by some, it is never the less consistent with both national and international policy stances, i.e. that trade is beneficial both to exporters and importers.

Overall, these results confirm the findings of Barrell and Pain (1997) and Bailey and Driffield (2002) that inward FDI does indeed generate a reduction in the demand for unskilled labour. While Barrell and Pain (1997) attribute this to the imported technology that accompanies inward investment, reducing the relative productivity of unskilled labour, it is also likely that there is an element of "crowding out" in domestic firms, following Driffield (1999) and Buffie (1993). As a result, while inward FDI may act to increase skill intensities in the UK, it has done little to provide employment for unskilled workers, despite the objective of reducing unemployment.

Equally, investment by the largest firms in the industry appears to have little impact on employment elsewhere in the sector. This suggests that encouraging or subsidising investment by large firms does not appear to stimulate growth in the SME sector, as policy makers and providers might hope. Other approaches are therefore required as part of a broader regionally-based industrial policy given the multiple 
policy objectives of RDAs, in particular in relation to fostering successful clusters and broader social inclusion (including reducing unemployment).

\section{Conclusions}

This paper argues that British industrial policy has typically shown features of discontinuity, inconsistency, reactiveness and a liberal stance. During the 1990s, Britain followed trends elsewhere in stressing the significance of 'competitiveness' (largely meaning productivity). Whilst potentially opening up a wide range of potential policy interventions, the apparent shift from sectoral to horizontal measures during the 1990s largely reduced the content of national level industrial policy. Rather, there was a narrowing of focus around the coalescing themes of support for small firms, attraction of foreign firms (FDI) and science and technology, all increasingly delivered via a regionally-based approach. During the late 1990s and post 2000, British industrial policy has been recast at the regional level, with the new Regional Development Agencies (RDAs) given responsibility for delivering industrial policy, in terms of targeting so-called 'clusters', attracting FDI and a broader social inclusion agenda. The 'cluster' concept has been problematic, however. In some cases sectors have simply been rebadged by RDAs as 'clusters' and more recently there has been the suggestion that RDAs are reverting to using the term sectors. In effect industrial policy is still a sectoral policy albeit one delivered at the regional level. In many cases the same 'clusters' are targeted across regions, in part because the DTI has controlled the cluster selection process in a top-down way whilst still pursuing a 'surrogate' industrial policy via its science and technology policy. A range of problems in policy design and delivery have been raised by the over-control of cluster selection and the simultaneous absence of coordination across regions. Even if the content of the new 'sectoral' measures are different (i.e. supporting 'clusters' of firms rather than 'picking' large 'national champions'), there remains the risk of repeating at the regional level previous national mistakes over targeting the 'wrong' clusters if the selection process is not democratically determined.

In pursuing a range of economic objectives including reduced unemployment and social inclusion, RDAs still see FDI as particularly important as part of this regionallybased industrial policy. The results in this paper, however, suggest that inward investment actually reduces the demand for unskilled labour. In so far as a key objective of regionally based industrial policies in attracting inward investment is to reduce structural unemployment, it is doubtful as to whether this is achieved by a 
heavy reliance on inward investment when the effect is to reduce demand for unskilled workers (the latter are often those most likely to experience long-term unemployment and be the target of policy intervention in the first place). This suggests that there is an incompatibility between the attraction of inward investment to reduce unemployment on the one hand and the goal of social inclusion on the other, suggesting in turn the need for greater attention in regionally-based industrial strategies to assist workers who lose out from such inward investment inflows. ${ }^{16}$

More broadly, and in line with Pitelis 2003 and Branston et al 2006, if a democratically-determined definition of competitiveness comprises a number of different objectives, then any 'new' British industrial policy focussed on competitiveness has to recognise the need for a range of policies as part of a joined up strategy that uses FDI where appropriate but that also requires measures to employ and/or train labour as part of an inclusion process. Similarly, our results suggest that encouraging or subsidising investment by large firms does not stimulate growth in the SME sector, as policy makers and providers might hope. Other policies are therefore required if SME growth is seen as an important object of industrial policy. If this is to be pursued at a regional level, then there needs to be range of policies which are democratically determined and which need to be properly aligned as part of regional strategies. This has yet to be properly recognised in regionallybased industrial policies in Britain. Rather, there has been the merging of elements of previous industrial and regional policies, under the narrow guise of a partial and inconsistent definition of 'competitiveness', all delivered at the regional level, with incompatibilities and tensions arising as a result.

\section{References}

Advantage West Midlands. (1999) Creating Advantage. The West Midlands Economic Strategy. Birmingham: Advantage West Midlands. Available at: http://www.advantagewm.co.uk/media/publications.asp

Amin, A and Thrift, N (1994) Living in the Global, in A Amin and N Thrift (eds), Globalization, Institutions and Regional Development in Europe. Oxford: OUP.

Amin, A and J Tomaney. 1995. The Regional Development Potential of Inward Investment in the Less Favoured Regions of the European Community, in A. Amin and J.Tomaney, ed.s., Behind the Myth of the European Union. London: Routledge.

\footnotetext{
${ }^{16}$ Trade, on the other hand, can have a beneficial effect on labour, with again the benefits being greater for skilled workers.
} 
Andriani, P, C Jones C, M Perkmann, L De Propris, V Sena, R Delbridge, K Möslein and A Neely. 2005. Challenging Clusters. The Prospects and Pitfalls of Clustering for Innovation and Economic Development. London: AIM Research.

Arellano, M. and Bond, S. 1988. Dynamic panel data estimation using DPD, a guide for users. Institute for Fiscal Studies Working Paper.

(1991. Some tests of specification for panel data: Monte Carlo evidence and an application to employment equations. Review of Economic Studies, 58: 277-97.

Bailey, D (2003). Explaining Japan's Kūdōka (Hollowing Out): A Case of Government and Strategic Failure? Asia Pacific Business Review, 2003, Vol.10, No.1.

(2003a) Globalisation, Regions and Cluster Policies: The Case of the Rover Task Force, Policy Studies, 2003, Vol.24, No.2/3.

Bailey, D. and Driffield, N.L. (2002) 'Hymer and Uneven Development Revisited: FDI and regional inequalities.' Contributions in Political Economy, Vol. 21 pp. 55-69.

Bailey, D, G Harte and R Sugden. (1994) British Policy towards Inward Investment. Journal of World Trade. 1994. Vol.28, No.2.

------ (1999) Regulating Transnationals: Free Markets and Monitoring in Europe, in Keith Cowling, ed., Practical Proposals for Industrial Policy in Europe. London: Routledge.

Baltagi, B. H. (2005) Econometric Analysis of Panel Data, $3^{\text {rd }}$ Edition, Chichester, Wiley.

Barrell, R and Pain, N. (1997). Foreign Direct Investment, Technological Change, and Economic Growth within Europe, Economic Journal, 107 (445): 1770-1786.

(1999), 'European growth and integration: domestic institutions, agglomerations and foreign direct investment in Europe', European Economic Review, April, pp. 925 -35 .

Begg, I et al. (1995) The Case for Decentralised Industrial Policy, in P Cheshire and I Gordon (eds) Territorial Competition in an Integrating Europe. Aldershot: Avebury.

Benneworth, P. (2001) Regional Development Agencies: The Early Years. Seaford: Regional Studies Association.

Blair, T. 2002. Message from the Prime Minister. Available at the Invest UK website at http://www.InvestUK.com

Brander J.A. and Spencer B.J. (1985) 'Export subsidies and international market share rivalry', Journal of International Economics, vol. 18, pp. 83-100.

Branston, J. R, Rubbini, L, Sugden, R and Wilson J R. 2006. The Healthy Development of Economies: A Strategic Framework for Competitiveness in the Health Industry, Review of Social Economy, forthcoming.

Brech, M and Sharp, M. 1984. Inward Investment: Policy Options for the United Kingdom. London: Routledge. 
Buffie, E F. (1993), 'Direct Foreign Investment, Crowding Out, and Underemployment on the Dualistic Economy'. Oxford Economic Papers 45(4), October 1993, pp.63967.

Charles, D and P Benneworth. (2001) Are we Realizing our Potential? Joining up Science and Technology Policy in the English Regions, Regional Studies, Vol 35, No 1.

Cooke, P and K Morgan. (1998) The Associational Economy: Firms, Regions and Innovations. Oxford: OUP.

Cowling, K. and Sugden, R. (1993). 'Industrial Strategy: A Missing Link in British Economic Policy', Oxford Review of Economic Policy, Vol 9, 83-100.

----- (1994). Beyond Capitalism. London: Pinter.

Cowling, K, C Oughton and R Sugden. (1999) A Reorientation of Industrial Policy? Horizontal Policies and Targeting, in Keith Cowling, ed., Practical Proposals for Industrial Policy in Europe. London: Routledge.

Department of Trade and Industry (DTI). (1994) Competitiveness: Helping Business to Win. London: HMSO.

------ (1995) Competitiveness: Forging Ahead. London: HMSO.

----- (1996) Competitiveness: Creating the Enterprise Centre of Europe. London: HMSO.

------ (1998) Our Competitive Future: Building the Knowledge Driven Economy. London: The Stationary Office.

Office.

(2005) UK Competitiveness Indicators: Second Edition. London: The Stationary

Doornik, J., Bond, S. and Arellano, M. (2002) 'Panel data estimation using DPD for Ox.' Available at http://www.nuff.ox.ac.UK/users/doornik/papers/dpd.pdf.

Driffield, N.L. (1999). 'The indirect employment effects of FDI into the UK.' Bulletin of Economic Research, Vol. 51(3) pp. 207-222.

----- (2001). The Impact on Domestic Productivity of Inward Investment in the UK, The Manchester School, 69(1): 103-119.

(2005) 'On the search for spillovers from FDI with spatial dependency.'. Regional Studies, forthcoming.

Driffield, N. and De Propris, L. (2005) 'FDI, clusters and technology sourcing.' The Cambridge Journal of Economics, forthcoming

Driffield, N.L. and Taylor, K. (2000) 'FDI and the labour market: A review of the evidence and policy implications.' Oxford Review of Economic Policy, Vol. 16(3) pp. 90-103.

Eaton J and Grossman G.M. (1986) 'Optimal trade and industrial-policy under oligopoly', Quarterly Journal of Economics, vol. 101 pp. 383-406.

EBRD (European Bank for Reconstruction and Development), 1998. Transition Report 1998. London: EBRD. 
El-Agraa, A. (1997) Ak Competitiveness Policy vs. Japanese Industrial Policy, The Economic Journal, Vol 107 No 444; 1504-1517.

Eltis, W. 1996. How Low Productivity and Weak Innovativeness undermined UK Industrial Growth, The Economic Journal, 106: 184-195.

Financial Times. (2004) "DTI's 5-year plan for scientific excellence greeted with caution", $17^{\text {th }}$ November 2004.

Florida, R. (1995). Toward the Learning Region, Futures, Vol. 27.

Fuller, C, R J Bennett and M Ramsden. (2002) The Economic Development Role of English RDAs: The Need for Greater Discretionary Power, Regional Studies, Vol 36, No 4.

Girma, S, Greenaway, D and Wakelin, K. 2001. Who Benefits from Foreign Direct Investment in the UK? Scottish Journal of Political Economy, 48(2): 119-133.

Gripaios, P, Gripaios R and Munday, M. 1997. The Role of Inward Investment in Urban Development: The Cases of Bristol, Cardiff and Plymouth, Urban Studies, 34(4): 579-603.

Hamermesh, Daniel S. (1995) 'Labour demand and the source of adjustment costs.' Economic Journal, 105 (430) pp. 620-634.

Harrison, B. (1994) Lean and Mean. The Changing Landscape of Corporate Power in the Age of Flexibility. New York: Basic Books.

Holtz-Eakin, D., Newey, W. and Rosen, H.S. 1988. Estimating vector autoregressions with panel data, Econometrica, Vol. 56 , 1371-1375.

House of Commons (2000) BMW, Rover and Longbridge: $8^{\text {th }}$ Report of the House of Commons Select Committee on Trade and Industry, 1999-2000 Session. London: House of Commons.

Görg, H. and Greenaway, D. (2004) Much ado about Nothing? Do domestic firms really benefit from foreign direct investment? World Bank Research Observer, 19(2), $171-197$.

Görg, H. and Strobl, E. (2001) Multinational Companies and Productivity Spillovers: A Meta-analysis, Economic Journal,111F, 723 - 739.

Gripaios, P, Gripaios R and Munday, M. 1997. The Role of Inward Investment in Urban Development: The Cases of Bristol, Cardiff and Plymouth, Urban Studies, 34(4): 579-603.

Jones, G. (2002) The development of the Annual Business Inquiry. Available at: http://www.statistics.gov.uk/themes/economy/Articles/General/extracts/downloads/de velopment of $\mathrm{ABI}$ Nov 2000.pdf

Lee, S. (1999). The Competitive Disadvantage of England, in Keith Cowling, ed., Practical Proposals for Industrial Policy in Europe. London: Routledge. 
Lovering, J. (1999) Theory led by Policy: the Inadequacies of the 'New Regionalism' (illustrated from the Case of Wales), International Journal of Urban and Regional Research, Vol 14.

----- (2001) The Coming Regional Crisis (and How to Avoid it), Regional Studies, Vol 35, no 4.

MacLeod, G. (2001) New Regionalism Reconsidered: Globalization and the Remaking of Political Economic Space, International Journal of Urban and Regional Research, Vol 25, No 4.

Markusen, A. (1996) Sticky Places in Slippery Space: A Typology of Industrial Districts, Economic Geography, Vol 72.

Martin and Sunley, (2003) Deconstructing Clusters: Chaotic Concept or Policy Panacea? Journal of Economic Geography, Vol.3, Iss.1: 5-35.

McCrone, G. (1999) Industrial Clusters: A New Idea or an Old One? Scottish Affairs, No 29.

OECD. (1992) Technology and the Economy: The Key Relationships. Paris: OECD.

------ (1998) Transition Report 1998. Paris: OECD.

Oughton, C. (1997) Competitiveness Policy in the 1990s, The Economic Journal, Vol 107 No 444.

Piore, M and C Sabel. (1984) The Second Industrial Divide: Possibilities for Prosperity. New York: Basic Books.

Pitelis, C. (1994) Industrial Strategy: For Britain, in Europe and the World, Journal of Economic Studies, Vol.21, No.5.

(2003) Supply-Side Strategy for Productivity, Competitivness and Convergence for the EU and CEECs, in Marinova, S and M A Marinov, ed.s, Foreign Direct Investment in Central and Eastern Europe. Aldershot: Ashgate.

Porter, M. (1990) The Competitive Advantage of Nations. Basingstoke: Macmillan.

------ (1998) Competitive Advantage: Creating and Sustaining Superior Performance. New York: Free Press.

Porter, M and Ketels, H M. (2003) UK Competitiveness: Moving to the Next Stage, DTI Economics Paper, No.2, London: DTI.

Putnam, R D. (1993) Making Democracy Work: Civic Traditions in Modern Italy. Princeton: Princeton University Press.

Pyke, F et al. (1990) Industrial Districts and Inter-Firm Co-operation in Italy. Geneva: International Institute for Labour Studies.

Reynolds, P and Coates, D. (1996). Conclusion, in D Coates, ed., Industrial Policy in Britain, Basingstoke: Macmillan. 
Saxenian, A L. (1994) Regional Advantage: Culture and Competition in Silicon Valley and Route 128. Boston: Harvard University Press.

Scott, A. (1996) Regional Motors of the Global Economy, Futures, Vol 28.

Storper, M. (1995) The Resurgence of Regional Economies, Ten Year Later: the Region as a Nexus of Untraded Interdependencies, European Urban and Regional Studies, Vol 2.

------ (1997) The Regional World: Territorial Development in a Global Economy. New York: Guilford.

Taylor, K. and Driffield, N.L. '(2005) Wage dispersion and the role of multinationals: Evidence from UK panel data. Labour Economics, 12 (1) 223-249

Theakston, 1996. Whitehall, Westminster and Industrial Policy, in in D Coates, ed., Industrial Policy in Britain, Basingstoke: Macmillan.

Tully, J and N Berkeley, (2004) Visualising the Operating Behaviour of SMEs in Scetor and Cluster: Evidence from the West Midlands, Local Economy, Vol.19 Iss.1,

Yannopoulos, G. and Dunning, J. 1976. Multinational Enterprise and Regional Development: an Exploratory Paper, Regional Studies, 10: 389-399.

Waters, R and H Lawton Smith. (2002) Regional Development Agencies and Local Economic Development: Scale and Competitiveness in High-technology Oxfordshire and Cambridgeshire, European Planning Studies, Vol 10, No 5.

Wren, C. (2001) The Industrial Policy of Competitiveness: A Review of Recent Developments in the UK, Regional Studies, Vol.35, Vol.9, 847-860. 
Table 1

Descriptive Statistics for Key Variables (1980-96)

\begin{tabular}{|c|c|c|c|c|c|c|}
\hline & $\begin{array}{l}\text { Value added } \\
\text { (£ million) }\end{array}$ & \begin{tabular}{|l|} 
Total \\
employment \\
(FTE)
\end{tabular} & \begin{tabular}{|l|} 
Total \\
unskilled \\
employment \\
(FTE)
\end{tabular} & $\begin{array}{l}\text { Total skilled } \\
\text { employment } \\
\text { (FTE) }\end{array}$ & $\begin{array}{l}\text { Average } \\
\text { unskilled } \\
\text { wage } \\
\text { (£ annual) }\end{array}$ & $\begin{array}{l}\text { Average } \\
\text { skilled } \\
\text { wage } \\
\text { (£ annual) }\end{array}$ \\
\hline average & 903.437 & 47748 & 31995 & 15752 & \multicolumn{2}{|c|}{\begin{tabular}{|l|l|l|l|l|} 
& 119257.694 .6
\end{tabular}} \\
\hline st. dev & 1102.41 & 54025.55 & 3528.569 & 22094 & 2820.461 & 4188.764 \\
\hline minimum & 13.000 & 1400 & 1100 & 200 & 5006.148 & 6474.627 \\
\hline maximum & 9409.400 & 313500 & 195200 & 168400 & 34275.3 & 70055.4 \\
\hline & $\begin{array}{l}\text { FDI } \\
\text { (£million) }\end{array}$ & \begin{tabular}{|l} 
Foreign \\
share in \\
value added
\end{tabular} & $\begin{array}{l}\text { Unskilled } \\
\text { employment } \\
\text { in top } 5 \text { firms }\end{array}$ & $\begin{array}{l}\text { Skilled } \\
\text { employment } \\
\text { in top } 5 \text { firms }\end{array}$ & $\begin{array}{l}\text { Investment } \\
\text { by top 5 } \\
\text { firms } \\
\text { (£ million) }\end{array}$ & $\begin{array}{l}\text { Imports } \\
\text { (£ million) }\end{array}$ \\
\hline average & 101.171 & 0.295 & 10416 & 5609 & 42.604 & 850.393 \\
\hline st. dev & 399.3429 & 0.144899 & 13219.77 & 90453.48 & 82.94994 & 1265.836 \\
\hline minimum & 0 & 0.000 & 400 & 100 & 0 & 0.900 \\
\hline maximum & 6138.106 & 0.764 & 110200 & 71300 & \multicolumn{2}{|c|}{961.6009599 .000} \\
\hline
\end{tabular}

All data based on SIC 3 digit industry level data

FTE $=$ Full Time Equivalent 
Bailey Driffield final paper for Journal of Industry, Competition and Trade 